\title{
DIFFICULTIES IN PREVENTING REPEATED GENITAL SELF-MUTILATION
}

Katarina Nikic Djuricic ${ }^{1}$, Marija Draskovic ${ }^{1}$, Andrea Obradovic ${ }^{1}$, Ivan Ristic ${ }^{2}$, Dragana Ignjatovic Ristic ${ }^{1}$ ${ }^{1}$ Psychiatry Clinic, Clinical Centre Kragujevac and Faculty of Medical Sciences, University of Kragujevac, Kragujevac, Serbia ${ }^{2}$ Medical Faculty, University of Belgrade, Belgrade, Serbia

\section{TEŠKOĆE U PREVENIRANJU PONOVLJENIH GENITALNIH SAMOPOVREĐIVANJA \\ Katarina Nikić Đuričić ${ }^{1}$, Marija Drašković ${ }^{1}$, Andrea Obradović1, Ivan Ristić², Dragana Ignjatović Ristić ${ }^{1}$ \\ ${ }^{1}$ Klinika za psihijatriju, Klinički centar Kragujevac i Fakultet medicinskih nauka, Univerziteta u Kragujevcu, Kragujevac, Srbija ${ }^{2}$ Medicinski fakultet, Univerziteta u Beogradu, Beograd, Srbija}

\begin{abstract}
Self-mutilation is self-inflicted and intentional damage done to one's body or one's body parts without a conscious suicidal intention. The first case of genital self-mutilation was published in 1846, and the first scientific description of genital self-mutilation was written by Stroch in 1901. Since the first case has been described, there have been a relatively small number of described cases of genital self-mutilation in both genders; there have been an even smaller number of cases of repeated genital self-mutilation and only a few descriptions of repetitive forms of male genital self-mutilation in the literature. The aim of our study is to present difficulties in preventing repeated male genital self-mutilation of a patient with an intellectual disability who was diagnosed and treated for epilepsy and psychosis in early adult life and had a previous history of self-destructive behaviour during childhood. Previous literature does not contain many repeated cases of male genital self-mutilation. After evaluating the contribution of each individual factor in the aetiology of self-mutilation, we concluded that every individual factor is significant in the aetiology of selfmutilation; however, no single factor, as well as all the factors put together, is not enough for prevention of self-mutilation. Our conclusion is that all the presented factors in our research (intellectual disability, epilepsy, psychosis, self-destructive tendencies in childhood) have their place in the aetiology of male genital selfmutilation, but none of them are determining factors. This confirms that it is necessary to conduct further research in the field of aetiology of male genital self-mutilation, which would contribute towards more adequate prevention.
\end{abstract}

Keywords: repetitive male genital self-mutilation, psychosis, epilepsy, intellectual disability

\section{SAŽETAK}

Samopovređivanje je namerno oštećenje tela ili delova tela, bez svesne suicidalne intencije. Prvi slučaj genitalnog samopovređivanja objavljen je 1846.godine, a Stroch je 1901 godine dao prvi naučni opis ovog fenomena. Nakon opisanog prvog slucaja u literaturi se pominje relativno mali broj slucajeva genitalnog samopovredjivanja, a jos manji broj slucajeva ponovljenog genitalnog samopovredjivanja od kojih je samo par zabelezeno kod osoba muskog pola. Cilj rada je da se ukaze na teskoce u preveniranju ponovljenog genitalnog samopovredivanja kod muškarca sa intelektualnim deficitom, koji je lečen od epilepsije i psihoze u ranom odraslom dobu, sa istorijom autodestruktivnih postupka u detinjstvu. U literaturi je malo opisa repetativnih formi genitalnog samopovređivanja kod muškaraca. Nakon alize svakog faktora ponaosob u etiologiji samopovredjivanja zakljucili smo da je svaki od njih znacajan za etiologiju samopovredjivanja; medjutim nijedan od njih pojedinacno kao ni svi zajedno nisu dovoljni da se prevenira samopovredjivanje. Naš zaključak je da svi navedeni faktori u našem istraživanju (intelektualni deficit, epilepsija, psihoza $i$ autodestruktivne tendencije $u$ detinjstvu) imaju svoje mesto u etiologiji genitalnog samopovredjivanja kod muskaraca, ali nijedan od njih nije determinišući. Ovim se potvrduje potreba za daljim istraživanjima u oblasti etiologije genitalne automutilacije kod muskaraca, koja bi doprinela adekvatnoj prevenciji.

Ključne reči: ponovljeno muško genitalno samopovređivanje, psihoza, epilepsija, intelektualni deficit 


\section{INTRODUCTION}

Self-mutilation is self-inflicted and intentional damage done to one's body or one's body parts without a conscious suicidal intention (1).

The first case of genital self-mutilation was published in 1846 (2), and the first scientific description of genital selfmutilation was written by Stroch in 1901 (3). Stroch linked the cause of genital self-mutilation of a 27 year old man with his failures in everyday life, not with sexual failure (3).

Since the first case was described, there has been a relatively small number of described cases of genital selfmutilation in both genders; a total of 110 cases have been described in the literature so far (4-7). There has been an even smaller number of cases of repeated genital self-mutilation reported in the literature. Genital self-mutilation is most common in the male population in their twenties and thirties, using a kitchen knife (8-10).

There were three described cases of male genital selfmutilation in Serbia (11). Interestingly, two cases happened within the same family, with both patients suffering from psychosis (11). In the third case, the patient did not suffer from a mental illness. A kitchen knife was used in all three cases (12).

Out of $87 \%$ cases of genital self-mutilation that are linked with psychosis, most of the patients were diagnosed with schizophrenia (23\%) (4). Religious delusions were the central psychopathological phenomenon in psychosis linked with genital self-mutilation (11).

Feelings of guilt caused by sexual conflicts accompanied by frequent masturbation in patients with psychosis can cause a strong and overwhelming need for self-punishment (11). Failure in partner relationships can be connected with genital self-mutilation, even in patients without psychosis (11).

Temporal lobe epilepsy can, in some cases, be linked with male genital self-mutilation (13). Reyazuddin described a case of genital self-mutilation in a patient with epilepsy that did not have any evident epileptic symptoms in the last six months before the genital self-mutilation. The author notes that genital self-mutilation might have been a byproduct of chronic epilepsy (7).

The connection between male genital self-mutilation and an intellectual disability is not clear. Some authors think that the connection between male genital self-mutilation and an intellectual disability is based on lack of insight and acuteness of the patient, while others see genital self-mutilation as a way of counterbalancing intrinsic aggressive tendencies (8).

The literature contains few descriptions of repetitive forms of male genital self-mutilation. There is no recent research on this subject, and only a few cases were described before 2002 (12).

The aim of our study is to present difficulties in preventing repeated male genital self-mutilation of a patient with an intellectual disability who was diagnosed and treated for epilepsy and psychosis in early adult life and had a previous history of self-destructive behaviour during childhood.

\section{CASE REPORT}

Patient, 32 years old, single, unemployed, Orthodox. The patient lives with his parents in a family house. The patient was born from a controlled pregnancy, naturally, on the due date, as the youngest of two children by married parents. He spoke his first words in time and started walking in his second year. The patient did not gain control of urinating during childhood, more precisely until he was 20 .

In his preschool period, the patient occasionally hit his head on the wall without any known or understandable reason (this behaviour stopped around the time he turned 15). He started school on time but was restless and often started fights with other children. When he was 8 years old, the patient was diagnosed with grand mal epilepsy. Despite being treated with antiepileptic drugs, the disease was not under control, and because of multiple weekly seizures, he stopped attending school. The patient was never hospitalized or properly diagnosed with epilepsy during a period of over twenty years.

The patient was not recruited for the military. The patient's mother describes him as a person who is extremely obedient, peaceful and reserved. The patient did not have any emotional relationships or sexual experience.

He does not smoke, drink or use psychoactive substances.

His great-grandfather committed suicide, and his uncle suffers from epilepsy.

When the patient was 30 years old (a year before the first self-mutilation), his parents noticed the first psychological symptoms; during a visit to his relatives, without any cause, the patient stopped all verbal communication. As his regression continued, periods of him talking to himself occurred, and he was brought to a psychiatrist. After being treated with antipsychotics, he started communicating with people in his environment once again.

At the time of the actual visit to the psychiatrist, his parents noted that when he was 31 years old, the patient hurt his genitals for the first time by making a small cut at the base of his penis. His father noticed shallow cuts while helping him maintain personal hygiene. The patient negated genital self-mutilation at first. Later on, he admitted to doing the act of genital self-mutilation in the bathroom using a kitchen knife while urinating. After the first genital self-mutilation, his parents did not ask for medical help and did not mention what occurred to the psychiatrist.

Seven months later, new genital self-mutilation occurred, after which the patient was hospitalized. Both cases of genital self-mutilation occurred after his parents stopped helping the patient in maintaining personal hygiene. The first genital self-mutilation occurred after his mother stopped her involvement, and the other occurred after his father stopped his involvement in this type of help.

Approximately ten days before the incident, the patient experienced disappointment after being rejected by a woman, which resulted in increased tension and anxiety. During the same period of time, the patient's interest in pornographic magazines and watching scenes with nudity on 
TV intensified. He masturbated multiple times a day when he felt increasingly nervous and anxious, which he did not mention to his parents. His patients thought that these events were the cause of the genital self-mutilation. The patient had no explanation for his behaviour. At the time of the patient's hospitalization, his parents informed us that they noticed that the patient had thoughts about cutting off his penis - he was visibly upset, and he often pulled up his pants to observe his genital area. During family meals, he showed increased anxiety while looking at the kitchen knife. He insisted that the knife stay on the table, but right after the lunch, he would remove the knife from the table first. Later on, he used the same knife to hurt himself.

On the day of the actual genital self-mutilation, the patient, while in his room, cut his penis with a kitchen knife, and then he walked into the living room with his pants lowered down and full of blood. The injury was surgically taken care of, and after consultation with a surgeon and urologist, he was taken to a psychiatrist. According to the psychiatrist's evaluation, the patient was upset and anxious and required hospital treatment, even though clear psychotic symptoms were not present. At the admission, the patient looked upset and tense; verbalization was limited and contact with him was superficial. He did not look like someone under the influence of psychotic symptoms, and he did not have suicidal thoughts or tendencies. At first, he did not want to talk about the act of genital self-mutilation. His anxiety reached psychotic level.

During the hospitalization of the patient, delusions or hallucinations were not present. Additionally, we did not notice any epileptic seizures during that period of time. After the first day in hospital, having adjusted his antipsychotic drug doses, the patient became more compliant endless tense, and his anxiety decreased. His laboratory results were normal. Examinations were performed in consultation with a neurologist, surgeon and a specialist of internal medicine, and they did not show any deviant findings important for the case of genital self-mutilation. Examination by a psychologist showed an intellectual disability (Intelligence quotient $=45-50)$ and potential organic changes.

During the hospitalization, he was treated with an antipsychotic (Pills Haloperidol $7.5 \mathrm{mg}$ ), antiepileptic (Carbamazepine $800 \mathrm{mg}$, Valproate $1000 \mathrm{mg}$ ) and an anxiolytic (Clonazepam $3 \mathrm{mg}$ ).

\section{DISCUSSION}

The patient, 32 years old, male, committed genital selfmutilation on two separate occasions. He has been diagnosed with an intellectual disability, epilepsy and psychosis. In a way, his diagnoses belong to all the aetiological frames that have a connection with male genital self-mutilation.

In the case of the patient, there is a similarity to the first scientific description of male genital self-mutilation given by Strochiz in 1901 (3). In both cases, genital self-mutilation was linked with bad experiences and failure in everyday life.
During the early childhood of the patient, he showed auto-destructive tendencies (1), such as hitting his head into the wall repeatedly, which can be related to his intellectual disability and explained as a way of modulating increased anxiety.

Additionally, data from the literature (11) show that one of the dominant factors that lead to male genital selfmutilation in patients with psychosis is the feeling of guilt because of sexual conflicts and failures. Frequent masturbation that follows these conditions causes a large amount of guilt and a strong, uncontrollable urge for self-punishment. In the case of this patient, we can assume that failure in obtaining contact with a woman led to frequent masturbation followed by an increased feeling of guilt and a strong urge for genital self-mutilation, but the patient did not confirm this.

Psychosis, a disorder most commonly associated with male genital self-mutilation, was diagnosed in the patient (4). However, in the period before and after the actual genital self-mutilation, no psychotic symptoms were manifested; neither could they be foreseen by observing his behaviour. Specifically, there were no religious delusions, which are the psychotic symptoms most commonly linked with male genital self-mutilation.

The intellectual disability that was diagnosed during the patient's early childhood by itself does not explain the genital self-mutilation. Its effect is on lowering his frustration threshold and limiting capacities for adaptation of his personality, especially while feeling neglected or denied.

The patient has also been diagnosed with grand mal epilepsy since he was eight years old. In the period before the genital self-mutilation, he did not have any epileptic seizures and was receiving a stable treatment of antiepileptic drugs. Therefore, genital self-mutilation in the patient cannot be linked with epilepsy.

Genital self-mutilation of the patient occurred during the period in which his parents stopped helping him maintain personal hygiene. We think that the act of genital selfmutilation was either a type of protest for feeling rejected by his parents or a compensation for his sexual impulses and emotions towards a young woman. The latter seems more plausible.

All of the analysed factors, which were previously mentioned and described, including auto destructive tendencies during childhood, psychosis, intellectual disability and epilepsy, cannot be directly linked to the actual genital selfmutilation.

Additionally, in an earlier study case that described genital self-mutilation of two men from the same family, none of the above mentioned factors could be directly linked with the actual genital self-mutilation (11).

\section{CONCLUSION}

These types of studies can help us discover potential causes of male genital self-mutilation. 
However, after taking into consideration all of the previously mentioned risk factors, we can conclude that they are relevant, but they not sufficient enough by themselves in determining the aetiology of male genital self-mutilation. Thus, attempts at creating strategies aimed at prevention of male genital self-mutilation should not be diminished.

This study also opens up a field of research for other potential causes, which could then help create adequate programmes for prevention and identification of men with a higher risk for genital self-mutilation.

\section{Acknowledgements}

Hereby authors would like to express gratitude to the Grant N¹75007 of Ministry of Science and Technological Development of The Republic Serbia, out of which this study was partially financed.

Hereby authors would like to express gratitude to the Junior projects ЈП 05/09 and ЈП 10/12 provided by Faculty of Medical Sciences, Unevrisity of Kragujevac.

The knowledge acquired in the project Research Ethics Education in the Balkans and Black Sea Countries, Fogarty International Program helped in preparation of this article.

We obtained informed consent from the parents of the patient we presented.

We express our gratitude towards Milica Borovcanin, psychiatrist, as the treating physician of the patient in this hospitalization, whose suggestions were invaluable during the preparation of this article.

\section{REFERENCES}

1. Feldman MD. The challenge of self-mutilation: A review. Comprehensive Psychiatry. 1988; 29:252-269.
2. Kharbach Y, Amiroune D, Ahsaini $M$ et al. Penile self-mutilation preceded by bizarre delusions: two case reports. Journal of Medical Case Reports 2014; $8: 246$

3. Stroch D. Self-castration [letter]. JAMA 1901;XXXVI(4): 270

4. Greilsheimer H, Groves JE. Male genital self-mutilation. Arch Gen Psychiatry 1979; 36(4):441-446

5. Becker H, Hartmann U. Genital self-inflicted injuriesphenomenological and differential diagnostic considerations from psychiatric viewpoint. Fortschr Neurol Psychiat 1997; 65.

6. Nakaya M. On background factors of male genital selfmutilation. Psychopatology 1996; 29:242-248

7. Reyazuddin M, Rizvi A, Usmani M, Gaur R. Penile Selfamputation in a Epileptic Patient Case Report. Delhi Psychiatry Journal 2014; 17:(2).

8. Lok U, Gulacti U, Benlioglu C, Buyukaslan H, Aktas N. Self Mutilation of Genitalia-Using Teeth. J Clin Diagn Res 2014 Feb; 8(2):179-180.

9. Stunell H, Power RE, Floyd M Jr, Quinlan DM. Genital self-mutilation. Int J Urol 2006 Oct; 13(10):1358-60.

10. Ignjatovic I, Potic B, Paunkovic Lj, Ravangard Y. Automutilation of the penis preformed by the Kitchen's knife. Int Urol and Nephrol. 2002; 34:113-5.

11. Ristic Ignjatovic D, Petrovic D, Ciric Z. Penile self-mutilation - two cases in one family. Psychiatria Danubina 2008; 20(3):332-6.

12. Catalano G, Catalano MC, Carroll KM. Repetative male genital self-mutilation: a case report and discussion of possible risk factors. J Sex Marital Ther 2002; 28(1):27-37.

13. Shakya DR, Shyangwa PM, Pandey AK, Subedi S, Yadav S. Self-injurios behavior in temporal lobe epilepsy. J Nepal Med Assoc 2010; 49(179):239-242. 